\title{
Relationship between serum testosterone concentrations and fertility in male mink (Mustela vison)
}

\author{
C. Sundqvist, A. Lukola* and Maija Valtonen $\dagger$ \\ Institute of Biology and *Department of Biochemistry and Pharmacy, Abo Akademi, Turku, and \\ $\dagger$ Central Laboratory, College of Veterinary Medicine, Helsinki, Finland
}

\begin{abstract}
Summary. During 7 successive months in 1982 and 1983 blood and semen samples were taken from male mink. The patterns of testosterone development in sterile and fertile males were readily distinguishable from each other. Testosterone concentrations showed a clear correlation $(r=0.73)$ with sperm quality of mink males. High testosterone levels $(16.0-24.5 \mathrm{ng} / \mathrm{ml})$ in early February were associated with defective sperm quality in March and low testosterone levels $(2 \cdot 0-13 \cdot 3 \mathrm{ng} / \mathrm{ml})$ with good sperm quality.
\end{abstract}

\section{Introduction}

Sterility in the male mink is not unusual. As one male usually serves several females the negative effect of male sterility rapidly multiplies, leading to groups of unfertilized females. Several efforts to overcome this problem have been made. The fertility of mink males has been checked by palpation of the testes (Onstad, 1967; Venge, 1973) and by a sperm test for which the semen is collected from females after interrupted mating (Venge, 1950; Rottensten, 1959; Onstad, 1967; Sundqvist \& Gustafsson, 1983). These methods, however, do not always give a good picture of the fertility of the male and the sperm test particularly must be performed by skilled personnel and under strictly controlled conditions to give satisfactory results.

This study was undertaken to determine whether serum testosterone concentrations in male mink of different degrees of fertility can be distinguished from each other and, furthermore, whether it is possible to assess fertility by a single measurement of testosterone concentration. The possibility of checking fertility using a simple blood test would greatly enhance the chances of effectively eliminating sterile males from breeding.

\section{Materials and Methods}

Animals, collection of blood and serum separation

The mink were kept in an open-air farm and were exposed to natural weather and daylight conditions. The experimental animals were treated in the same way as the farm stock, which were provided with food and water ad libitum.

Ten mink males of the Sapphire breed were selected at random in September from a population of $60 \mathrm{mink}$ and this group was bled once a month over a period of 7 consecutive months. Ten extra males were bled in February. The samples of blood were collected at 10:00-12:00 h to avoid diurnal variations in hormonal levels. 
Cutting a nail is nowadays a common method of collecting blood from mink to study blood characteristics (Jepsen, Poulsen \& Jørgensen, 1981). The method works well when capillary tubes (Microtainer: Becton \& Dickinson) are used and there is no need for large quantities of blood. In this way it was possible to collect blood without anaesthesia. The blood samples were allowed to stand for $30 \mathrm{~min}$ before being centrifuged at $10080 \mathrm{~g}$ in a Beckman Spinco Microfuge for $5 \mathrm{~min}$. Samples were stored frozen at $-20^{\circ} \mathrm{C}$ until they were analysed 1-7 months later.

\section{Determination of testosterone concentration}

The testosterone ( $\left.{ }^{125} \mathrm{I}\right)$ Radioimmunoassay Kit by Farmos Diagnostica was used to measure testosterone concentration in the serum. The antiserum cross-reacts $18 \%$ with $5 \alpha$-dihydrotestosterone, but in mink $5 \alpha$-dihydrotestosterone is produced in such small amounts that the error due to this cross-reactivity accounts for $5 \%$ according to Boissin-Agasse, Maurel \& Boissin (1981). The sensitivity of the assay was $0 \cdot 15 \mathrm{ng} / \mathrm{ml}$ and the within-assay coefficient of variation was $8.7 \%$.

\section{Assessing the fertility of mink males}

A sperm test has been used for several years as a routine method for checking the fertility of mink males at our farm (Sundqvist \& Gustafsson, 1983). The semen is collected from females immediately after interrupted mating, lasting no more than $15-20 \mathrm{~min}$. Sperm counts were made in duplicate with a haemocytometer. Males with $<1 \times 10^{6}$ spermatozoa/ml were classified as sterile and with $1 \times 10^{6}-150 \times 10^{6}$ spermatozoa/ml were classified as fertile. Semen quality was checked 2-5 times during the breeding season in March.

\section{Results}

Testosterone concentrations in sterile and fertile males

The peripheral concentrations of serum testosterone changed differently over 7 months (September to March) in males that were sterile or fertile in the breeding season (Text-fig. 1). Mean ( \pm s.d.) serum testosterone concentrations was low from September to November (3.64 \pm 3.55 and $3.61 \pm 2.66 \mathrm{ng} / \mathrm{ml}$ ) in both groups. Fertile males showed a moderate increase in

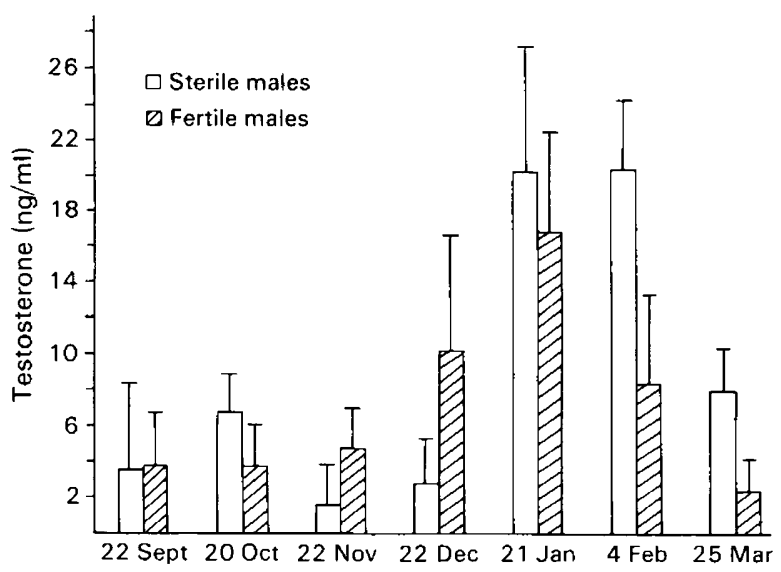

Text-fig. 1. Serum testosterone concentrations (mean \pm s.d.) in blood samples taken from sterile and fertile male mink at different times. Five males in each group were used. In February, however, 6 sterile and 14 fertile males were analysed. 
testosterone in December $(10.32 \pm 6.31 \mathrm{ng} / \mathrm{ml})$, with peak levels in late January $(16.73 \pm 4.70$ $\mathrm{ng} / \mathrm{ml})$. Testosterone values then declined steeply to reach basal levels in late March $(1.90 \pm 1.67$ $\mathrm{ng} / \mathrm{ml}$ ). In early February fertile males had $8 \cdot 32 \pm 4.95 \mathrm{ng}$ testosterone $/ \mathrm{ml}$ serum.

Sterile males show the same pattern of testosterone development as fertile males from September to November, but the values in late December were lower $(2.83 \pm 2.60 \mathrm{ng} / \mathrm{ml}, P<$ $0.05)$. The increase after the nadir occurred later in sterile than fertile males but peak levels $(20 \cdot 33$ $\pm 7.02 \mathrm{ng} / \mathrm{ml})$ were reached in late January. Values were still high in early February $(20.47 \pm 3.88$ $\mathrm{ng} / \mathrm{ml} ; P<0.05$ ) compared with those for fertile males on the same date.

\section{Correlation between testosterone and fertility}

After obtaining information about testosterone levels in fertile and sterile males during the period before the breeding season it was possible to search for an optimum date when testosterone and fertility would correlate. There was a correlation $(r=0.73)$ between high values of testosterone in early February and low sperm quality in the breeding season. One male had a high testosterone concentration but good sperm quality and one male with a high concentration of testosterone was sterile at the beginning of breeding season, as expected, but had good sperm quality by the end of the season.

\section{Discussion}

Our observations about increased concentration of serum testosterone in mink males between December and January and declining concentrations after peak levels in late January correspond with previous reports (Nieschlag \& Bieniek, 1975; Boissin-Agasse \& Boissin, 1979; Pilbeam, Concannon \& Travis, 1979). In these reports no observations of clear differences between sterile and fertile males and their testosterone levels were made. In our study testosterone began to increase later in sterile than fertile males and the increase in testosterone was much sharper in sterile males. Testosterone dropped sharply in early February in fertile males, as reported by Nieschlag \& Bieniek (1975) and Boissin-Agasse \& Boissin (1979). Testosterone did not decline at all in sterile males at the same date. This clear difference between fertile and sterile males could be detected only after checking testosterone 2 weeks after the peak values. It is therefore important to take samples at short intervals.

All males showing a sharp decline in testosterone concentration in early February were fertile ( 7 males with excellent sperm quality and 5 males with good sperm quality). All males (except one which had good sperm quality) that still had high levels of testosterone in their blood in early February were sterile. The other male that had a high testosterone concentration in early February and had good sperm quality by the end of the breeding season could have just attained sexual maturity much later than did average males. Late maturing males can be induced to reach sexual maturity by therapy with hCG (Valtonen, Lukola, Sundqvist \& Lohi, 1982).

By clinical examination of mink males, individuals with testicular anomalies can be excluded from breeding (Onstad, 1967). The semen quality may, however, be poor in spite of the testes being normally developed. In the present study the observed sterile males were clinically normal and had a normal to strong libido. However, the present results indicate that, by measuring the serum testosterone concentration in early February, it is possible to eliminate sterile males even at this stage. The sperm test normally performed during the breeding season would then be unnecessary.

The explanation for the failure of the serum testosterone concentration to decrease in February in sterile males is not understood. The high testosterone content is, however, an indication of an intact hypothalamo-pituitary axis and functional Leydig cells in these males. The measurement of LH would provide information about the degree of pituitary activity. The lipid content in interstitial tissue varies seasonally and is highest in mink before the mating season. It then 
decreases in the period just before and during the mating season (Onstad, 1967). It might therefore be concluded that lipids, especially cholesterol, in the Leydig cells could serve as precursors of androgen production. Histological examination of the testes of males tested for sterility 2-5 times by the sperm test revealed a greater number of Leydig cells compared with the testes of fertile males (C. Sundqvist, unpublished). This might partly explain the prolonged production of androgen.

\section{References}

Boissin-Agasse, L. \& Boissin, J. (1979) Variations saisonnières du volume testiculaire et de la testostéronémie chez deux mustélidés: le furet (Mustela furo L.) et le vison (Mustela vison S.). J. Physiol., Paris 75, 227-232.

Boissin-Agasse, L., Maurel, D. \& Boissin, J. (1981) Seasonal variations in thyroxine and testosterone levels in relation to the moult in the adult male mink (Mustela vison Peale and Beauvois). Can J. Zool. 59, 1062-1066.

Jepsen, O.R., Poulsen, J.S.D. \& Jorgensen, G. (1981) Collection of blood, sedation and anaesthesia in mink. Acta vet. scand., Suppl. 1, 9-99.

Nieschlag, E. \& Bieniek, H. (1975) Endocrine testicular function in mink during the first year of life. Acta endocr.,Copenh. 79, 375-379.

Onstad, O. (1967) Studies on postnatal testicular changes, semen quality, and anomalies of reproduc- tive organs in the mink. Acta endocr., Copenh. Suppl. $117,1-117$.

Pilbeam, T.E., Concannon, P.W. \& Travis, H.F. (1979) The annual reproductive cycle of mink (Mustela vison). J. Anim. Sci. 48, 578-584.

Rottensten, K. (1959) Saedkvalitet og ufrugtbarhed hos minken. Dansk Pelsdyravl 22, 215-217.

Sundqvist, C. \& Gustafsson, M. (1983) Sperm test-a useful tool in breeding work of mink. Maataloust. Aikakausk. 55, 119-131.

Valtonen, M., Lukola, A., Sundqvist, C. \& Lohi, O. (1982) Gonadotropinbehandling av minkhanar. NJF-möte on pälsdjursproduktionen, Ålesund, Norway.

Venge, O. (1950) Spermakontroll hos mink. Våra Pälsdjur 21, 79-80.

Venge, O. (1973) Reproduction in the mink. K. Vet.-og Landbohoisk. Aarsskr. 95-146.

Received 20 May 1983 